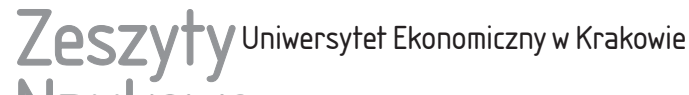 Naukowe
}

\section{Pokryzysowy system rządzenia w Unii Europejskiej}

\section{Streszczenie}

Celem artykułu jest analiza pokryzysowego systemu rządzenia w Unii Europejskiej, która pozwoli udzielić odpowiedzi na pytania, jak kształtuje się pokryzysowy system rządzenia oraz jaki jest kierunek prowadzonych działań; innymi słowy, czy mamy do czynienia z budowaniem unii gospodarczej, unii finansowej, unii fiskalnej, czy może również zrębów unii politycznej. W opracowaniu zastosowano analityczno-deskryptywną i systemową metodą badawczą. Z przeprowadzonej analizy wynika, że istotnie mamy do czynienia z kształtowaniem się nowego modelu rządzenia, co więcej, wzmocniony został wymiar gospodarczy Unii, natomiast wymiar polityczny pozostaje zasadniczo bez zmian.

Słowa kluczowe: Unia Europejska, kryzys, unia bankowa, rynki finansowe.

Klasyfikacja JEL: E42, F33.

\section{Wprowadzenie}

Kryzys gospodarczy i finansowy, jaki dotknął Unię Europejską, a w szczególności państwa strefy euro, sprawił, że konieczne stało się podjęcie natychmiastowych środków zaradczych. Działania te podejmowane były na podstawie traktatów europejskich, ale także wykraczały poza ich ramy, z zastosowaniem instrumentów prawa miękkiego (soft law) i prawa twardego (hard law), angażowały instytucje unijne bądź też były realizowane bez ich udziału, co naruszyło

Danuta Kabat-Rudnicka, Uniwersytet Ekonomiczny w Krakowie, Wydział Ekonomii i Stosunków Międzynarodowych, Katedra Polityki Ekonomicznej i Programowania Rozwoju, ul. Rakowicka 27, 31-510 Kraków, e-mail: kabatd@uek.krakow.pl 
dotychczasową równowagę i zasady funkcjonowania UE. Pomimo skomplikowanej sytuacji i trudności w osiąganiu porozumienia pomiędzy państwami członkowskimi kryzys uświadomił europejskim decydentom, że zmiana, aczkolwiek trudna do przeprowadzenia, jest możliwa, a nawet konieczna.

Należy zauważyć, że działania na rzecz integracji rynków finansowych w Unii podejmowane były już wcześniej, nierzadko na podstawie niewiążących wytycznych, $\mathrm{tj}$. z wykorzystaniem instrumentów prawa miękkiego. Natomiast kryzys sprawił, że prawo miękkie zostało zastąpione przez instrumenty prawa twardego, mające moc wiążącą.

W związku z tymi spostrzeżeniami nasuwają się pytania, jak kształtuje się pokryzysowy system rządzenia w UE oraz w jakim kierunku zmierzają podejmowane działania; innymi słowy, czy mamy do czynienia z budowaniem unii gospodarczej, unii finansowej, unii fiskalnej, czy może również zrębów unii politycznej [Juncker i in. 2015] ${ }^{1}$. Artykuł ma na celu ukazanie działań podejmowanych w ramach unijnego pokryzysowego systemu rządzenia. Hipoteza badawcza sprowadza się do twierdzenia, że mamy do czynienia ze wzmocnieniem gospodarczego filara UE, natomiast unia polityczna pozostaje nadal kwestią otwartą.

\section{Zarządzanie rynkiem finansowym w Unii Europejskiej}

Kryzys gospodarczy i finansowy wpłynął na zmianę sposobu myślenia o gospodarce i finansach i sprawił, że coraz częściej mówi się o potrzebie nowego podejścia do zarządzania UE. Unia nastawiona programowo na sukces stanęła w związku z kryzysem wobec konieczności podjęcia środków zaradczych. Nierzadko wychodziła w tym celu poza ramy traktatów, wykorzystywała instrumenty międzynarodowego prawa publicznego, jak również instrumenty prawa miękkiego, co stanowi odejście od metody wspólnotowej.

Nowy sposób rządzenia (new mode of governance), stanowiący alternatywę dla podejścia nakazowego, sprowadza się do pogłębiania współpracy oraz współtworzenia norm przez różne podmioty, natomiast w praktyce jest odchodzeniem od metody wspólnotowej, która ogranicza się do odgórnych procesów (inicjatywa Komisji, decyzja podejmowana przez Parlament Europejski (PE) i Radę, a jeśli pojawią się kwestie sporne, angażowany jest Trybunał Sprawiedliwości (TS) [Dehousse 2016]). To nowe podejście wykorzystuje w większym stopniu instrumenty prawa miękkiego, które nie narzucają norm kategorycznie i sprowadzają

\footnotetext{
${ }^{1} \mathrm{~W}$ dokumencie jest mowa o zmianie, która winna zmierzać w czterech kierunkach, mianowicie: unii gospodarczej, unii finansowej, która z kolei pociąga za sobą konieczność dokończenia unii bankowej oraz przyspieszenie prac nad unią rynków kapitałowych, unii fiskalnej, last but not least unii politycznej.
} 
się raczej do naśladownictwa i wzajemnej oceny niż do formalnej presji. Równie ważne jest to, że rozwój nowych mechanizmów może stać się sposobem na umacnianie władzy UE w tych obszarach, z których jest ona wyłączona, jako że pozostają one w gestii państw członkowskich [Dehousse 2016]. Dodać należy, że Unia już wcześniej, tj. przed kryzysem 2008 r., wykorzystywała instrumenty prawa miękkiego do zarządzania rynkiem finansowym Unii.

Zarządzanie rynkiem finansowym w UE zostało istotnie zmienione, tak że można powiedzieć, że obecnie jest to reżim najbardziej wyspecjalizowany. Z punktu widzenia ewolucji zarządzania rynkiem finansowym UE ważną cezurę stanowi 2001 r., kiedy to powstał raport komisji pracującej pod przewodnictwem A. Lamfalussy'ego, który zalecał wypracowywanie lepszego prawa przez prowadzenie otwartych i przejrzystych konsultacji oraz spójną implementację w drodze delegowania władzy do komisji nadzorczych składających się z niezależnych ekspertów ${ }^{2}$. Drugim ważnym wydarzeniem był przygotowany w 2009 r. raport zespołu pracującego pod przewodnictwem J. de Larosière'a, na podstawie którego w miejsce komisji powołano europejskie urzędy nadzorcze, natomiast niewiążące wytyczne zastąpiono wiążącymi standardami technicznymi, obecnie tworzącymi jednolity zbiór przepisów oraz jeden z filarów unii bankowej [Kudrna 2016]. Kolejne reformy szły więc w kierunku większej skuteczności w tworzeniu prawa, a nowy reżim ewoluował w stronę większej otwartości i transparentności i tym samym stawał się bardziej włączający. Należy też zauważyć, że zmiany zapoczątkowane w 2005 r. są obecnie wprowadzane w życie wraz z reformami 2013 r. [Kudrna 2016].

Reformy zwiększały przede wszystkim skuteczność polityki przez zastosowanie nowych instrumentów, jak również większą inkluzywność przez wprowadzenie bardziej otwartego i przejrzystego procesu konsultacji, chociaż nie zwiększały w istotny sposób demokratycznej legitymacji dla przyjmowanych regulacji finansowych z powodu ich złożonego charakteru oraz ze względu na fakt, że wiele istotnych decyzji podejmowanych jest na szerszym (pozaunijnym) forum, gdzie obecne są tylko niektóre państwa UE [Kudrna 2016].

Reformy A. Lamfalussy'ego wprowadziły rozwiązania charakterystyczne dla nowego modelu rządzenia, po to by osiągnąć odpowiedni stopnień harmonizacji prawa i spójnej implementacji w całej Unii, natomiast reformy J. de Larosière'a zastąpiły niewiążące wytyczne wiążącymi standardami technicznymi, które tworzą obecnie jednolity zbiór przepisów. Z analogicznym procesem mamy do czynienia w przypadku nowo tworzonych jednostek. Komitet Doradczy ds. Bankowości (Banking Advisory Committee - BAC [Directive 2000/12/EC])

\footnotetext{
${ }^{2}$ Ogólne, ramowe zasady winny być stanowione w drodze procedur legislacyjnych, natomiast o kwestiach bardziej technicznych powinna decydować Komisja Europejska przy wsparciu komisji nadzorczych (Securities Committee oraz Securities Regulators Committee). Zob. [Final Report... 2001, s. 19].
} 
został zastąpiony przez Europejski Komitet Bankowy (European Banking Committee - EBC [Decyzja Komisji 2004/10/WE]), natomiast Komitet Europejskich Organów Nadzoru Bankowego (Committee of European Banking Supervisors - CEBS [Decyzja Komisji 2004/5/WE]) został następnie zastąpiony przez Europejski Urząd Nadzoru Bankowego (European Banking Authority - EBA [Rozporządzenie Parlamentu Europejskiego i Rady (UE) nr 1093/2010]).

Należy zauważyć, że regulacje rynku finansowego koncentrują się na trzech segmentach, na które składają się: bankowość, ubezpieczenia oraz papiery wartościowe. Natomiast z uwagi na to, że regulacje finansowe mają zdecydowanie techniczny charakter, Komisja poszukiwała wsparcia ze strony komitetu ekspertów takiego jak wspomniany $\mathrm{BAC}^{3}$, którego prace zdominowały kwestie dotyczące wzajemnego otwarcia i równego dostępu do rynków krajowych [Kudrna 2016]. Dodać należy, że Komisja zainicjowała swój plan działania w dziedzinie usług finansowych (Financial Services Action Plan - FSAP) już w 1999 r., stawiając sobie za cel ograniczenie fragmentaryzacji regulacyjnej, ściślejszą współpracę urzędów nadzorczych oraz zapewnienie prawdziwie jednolitego rynku finansowego [Financial Services... 1999]. Następnie pod przewodnictwem A. Lamfalussy'ego Komisja nakreśliła reformy, które miały poprawić skuteczność zarządzania rynkiem finansowym.

Reforma reorganizowała zarządzanie rynkiem finansowym na kilku poziomach: pierwszy dotyczył tradycyjnej metody wspólnotowej; drugi - Europejskiego Komitetu Bankowego (EBC), następcy BAC, który w imieniu państw członkowskich doradza Komisji w sprawach związanych z działalnością bankową, trzeci - najbardziej innowacyjny, Komitetu Europejskich Organów Nadzoru Bankowego (CEBS), będącego niezależną doradczą grupą nadzoru bankowego z określonym mandatem, wiążącym programem działania, niezależnością ekspertów i własnym budżetem [Kudrna 2016].

Znaczącą innowacją było natomiast zwiększenie przejrzystości i otwartości procesu regulacyjnego. CEBS został zobowiązany do przedstawiania corocznego i wieloletniego programu działań oraz swoich osiągnięć w dorocznym raporcie, który tworzył nowy mechanizm odpowiedzialności, co zostało następnie wzmocnione przez obowiązkowe i transparentne konsultacje. Poprawiła się również skuteczność proceduralna CEBS dzięki niezależności ekspertów. Jakkolwiek CEBS opierał się na pracy krajowych ekspertów, to przestał być jedynie siecią administracyjną koordynującą prace narodowych ekspertów. Zyskał własne zdolności eksperckie, poszukując prawdziwie europejskich rozwiązań wykraczających poza kompromis minimum [Kudrna 2016]. Chociaż wytyczne, rekomendacje i standardy nie były prawnie wiążące i musiały być przyjmowane w drodze jedno-

\footnotetext{
${ }^{3}$ Pierwsza dyrektywa bankowa ustanowiła tzw. Komitet Doradczy (Advisory Commitee). Zob. [First Council Directive (77/780/EEC) of 12 December 1977].
} 
myślnej decyzji, to CEBS zobowiązywał każdego do przedstawienia prawnych, politycznych i technicznych przeszkód uniemożliwiających podporządkowanie się im [Kudrna 2016].

Reforma A. Lamfalussy'ego została implementowana przed 2007 r. i nie mogła zmienić ram regulacyjnych tak dalece, aby zapobiec kryzysowi finansowemu lub też złagodzić jego skutki i uczynić je bardziej podatnymi na zarządzanie. Co prawda CEBS mógł stopniowo doskonalić techniczne aspekty istniejących już regulacji, lecz nie mógł tworzyć nowych. Natomiast kryzys dał silny bodziec do reform, jeśli chodzi o treść, jak i o ramy regulacyjne [Kudrna 2016].

Odpowiedzią regulacyjną na kryzys były wyniki prac komitetu pod przewodnictwem J. de Larosière'a, który zalecił podniesienie komisji nadzorczych do rangi europejskich urzędów nadzorczych (European Supervisory Authorities - ESA) ${ }^{4}$. Urzędy te sprawują w skali mikro nadzór ostrożnościowy nad rynkami finansowymi, podczas gdy Europejska Rada ds. Ryzyka Systemowego (European Systemic Risk Board - ESRB) sprawuje nadzór ostrożnościowy w skali makro, i tworzą wraz ze Wspólnym Komitetem Europejskich Urzędów Nadzoru (Joint Committee of the European Supervisory Authorities) oraz właściwymi organami lub organami nadzoru państw członkowskich Europejski System Nadzoru Finansowego (European System of Financial Supervision - ESFS).

W ramach nowych rozwiązań CEBS zostało przekształcone z końcem 2010 r. w jeden z trzech wspomnianych urzędów, tj. Europejski Urząd Nadzoru Bankowego, będący niezależną agencją posiadającą osobowość prawną i bezpośrednio odpowiedzialną przed PE i Radą. Mandat EBA obejmuje m.in.: opracowywanie regulacyjnych i wykonawczych standardów technicznych, wydawanie wytycznych i zaleceń kierowanych następnie do właściwych organów lub instytucji finansowych, wspieranie spójnego stosowania prawa unijnego oraz rozstrzyganie sporów pomiędzy właściwymi krajowymi organami nadzorczymi w sytuacjach transgranicznych itp. [Rozporządzenie Parlamentu Europejskiego i Rady (UE) nr 1093/2010, art. 10, 15, 16, 17 i 19]. Następnie w terminie trzech miesięcy od otrzymania projektu regulacyjnego standardu technicznego Komisja podejmuje decyzję w sprawie jego zatwierdzenia. Komisja może zatwierdzić projekt regulacyjnych standardów technicznych tylko częściowo lub ze zmianami, jeżeli uzna, że leży to w interesie Unii (art. 10). Analogicznie w terminie trzech miesięcy od otrzymania projektu wykonawczego standardu technicznego Komisja podejmuje decyzję w sprawie jego zatwierdzenia, przy czym może przedłużyć termin o miesiąc. Podobnie jak w przypadku regulacyjnych standardów technicznych

\footnotetext{
${ }^{4}$ ESA tworzą: Europejski Urząd Nadzoru Bankowego, Europejski Urząd Nadzoru Ubezpieczeń i Pracowniczych Programów Emerytalnych (European Insurance and Occupational Pensions Authority - EIOPA) oraz Europejski Urząd Nadzoru Giełd i Papierów Wartościowych (European Securities and Markets Authority - ESMA).
} 
Komisja może zatwierdzić projekt wykonawczego standardu technicznego tylko częściowo lub ze zmianami, jeśli wymaga tego interes Unii (art. 15).

Nowością w ramach posunięć reformujących zarządzanie rynkiem finansowym UE było wyposażenie w kompetencje ponadnarodowe EBA. Agencja ta może w nadzwyczajnych sytuacjach podjąć decyzję indywidualną skierowaną do instytucji finansowej, zobowiązującą tę ostatnią do podjęcia działań niezbędnych do właściwego wypełnienia obowiązków wynikających z przepisów prawa, w tym również do zaprzestania określonych praktyk. Chodzi mianowicie o takie sytuacje, gdy organ nie stosuje aktów prawodawczych, w tym regulacyjnych standardów technicznych i wykonawczych standardów technicznych, lub gdy stosuje je w sposób, który stanowi ich wyraźne naruszenie, oraz w przypadkach gdy pilne podjęcie środków zaradczych staje się konieczne dla przywrócenia prawidłowego funkcjonowania rynków finansowych i ich integralności lub stabilności systemu finansowego w całej Unii lub w jej części (art. 18 ust. 4). EBA może także wydać decyzję w sytuacji, gdy zainteresowane organy nie są w stanie osiągnąć porozumienia $\mathrm{w}$ fazie postępowania pojednawczego $\mathrm{w}$ celu rozstrzygnięcia sporu, zobowiązującą je do podjęcia określonych działań lub do powstrzymania się od nich ze skutkami wiążącymi dla nich, a to wszystko w celu zapewnienia zgodności działań z prawem Unii (art. 19 ust. 3). Natomiast jeśli organ nie stosuje się do decyzji EBA, może ona wydać decyzję indywidualną skierowaną do instytucji finansowej, zobowiązującą tę ostatnią do podjęcia działań niezbędnych do wypełnienia obowiązków wynikających z prawa Unii, w tym do zaprzestania określonych praktyk (art. 19 ust. 4). W tych i jeszcze dwóch innych przypadkach (art. 17 ust. 6 i art. 18 ust. 3) EBA zastępuje krajowe urzędy nadzoru, działając jak organ ponadnarodowy.

Reforma J. Larosière’a przyniosła trzy istotne zmiany. Umocowała ekspertów w ESA, których projekty standardów technicznych nie są już tylko zwykłym doradztwem, ponieważ wobec braku sprzeciwu ze strony Parlamentu i Rady Komisja jest zobowiązana do zatwierdzenia ich bez zmian, natomiast w sytuacji gdy zamierza dokonać zmian lub nie zamierza zatwierdzić standardów, jest zobowiązana do podania uzasadnienia (art. 14). Co więcej, idee, które CEBS wyrażało w niewiążących wytycznych, teraz materializują się w wiążących standardach technicznych, co oznacza de facto „twardnienie” prawa miękkiego. Ponadto kompetencje EBA w sytuacjach nadzwyczajnych, jak i wówczas gdy rozstrzyga spory, wskazują na to, że pozostaje już tylko krok od zastąpienia bliskiej współpracy urzędów krajowych prawdziwie ponadnarodowym reżimem rządzenia [Kudrna 2016].

Reasumując, pokryzysowe zarządzanie wprowadza dodatkowe ponadnarodowe elementy, które mają zastosowanie w odniesieniu do państw strefy euro oraz do tych państw członkowskich, które zdecydowały się na przystąpienie do unii bankowej. Co istotne, techniczne standardy EBA awansowały do jednolitego 
zbioru przepisów ${ }^{5}$, stanowiąc jeden z filarów unii bankowej. Zadaniem EBA jest więc rozwijanie jednolitej kultury nadzorczej w państwach członkowskich, natomiast do Europejskiego Banku Centralnego (EBC) należy zapewnianie spójnego nadzoru nad wszystkimi bankami w państwach uczestniczących w unii bankowej [Kudrna 2016].

\section{Unia gospodarcza, finansowa, fiskalna, czy polityczna?}

W sprawozdaniu przewodniczącego Komisji Europejskiej przygotowanym w ścisłej współpracy z przewodniczącym szczytu państw strefy euro, przewodniczącym Eurogrupy, prezesem Europejskiego Banku Centralnego oraz przewodniczącym Parlamentu Europejskiego przyjęte zostało ustalenie, że działania pokryzysowe winny być prowadzone w czterech kierunkach i obejmować działania na rzecz: prawdziwej unii gospodarczej, dzięki której każda gospodarka narodowa będzie posiadała cechy dające jej możliwość pomyślnego rozwoju w ramach unii walutowej; unii finansowej, gwarantującej integralność euro w całej unii walutowej i zwiększającej udział sektora prywatnego w podziale ryzyka, co z kolei wiąże się z koniecznością dokończenia unii bankowej oraz przyspieszenia prac nad unią rynków kapitałowych; unii fiskalnej, zapewniającej zarówno długookresową stabilność budżetową, jak też fiskalny mechanizm stabilizacyjny; unii politycznej, która stanowi podstawę wszystkich powyższych przedsięwzięć dzięki prawdziwej demokratycznej odpowiedzialności i wzmocnieniu instytucjonalnemu [Juncker i in. 2015]. Jak wiadomo, do najmniej zaawansowanych należą prace nad unią polityczną, natomiast najbardziej zaawansowane wydają się prace ukierunkowane na tworzenie unii finansowej, w tym prace związane z tworzeniem unii bankowej.

Unia bankowa stanowi przykład wysoce scentralizowanego reżimu prawnego, mającego zapewnić nadzór ostrożnościowy oraz restrukturyzację i uporządkowaną likwidację instytucji kredytowych w strefie euro oraz w tych państwach, które dołączyły do unii bankowej. Jest to więc reżim o złożonym układzie instytucjonalnym, w którym decyzje co do zasady podejmowane są na poziomie ponadnarodowym, zwłaszcza w odniesieniu do największych i najważniejszych instytucji kredytowych o systemowym znaczeniu [Hadjiemmanuil 2015a]. Tak pomyślana unia bankowa opiera się na trzech filarach: jednolitym mechanizmie nadzorczym, jednolitym mechanizmie restrukturyzacji i uporządkowanej likwidacji oraz jednolitym mechanizmie gwarantowania depozytów [Alexander 2015, Baglioni 2016].

${ }^{5} \mathrm{~W}$ skład jednolitego zbioru przepisów wchodzą: rozporządzenia, dyrektywy, wytyczne, standardy i opinie - narzędzie służące zwiększeniu konwergencji oraz promowaniu wspólnego podejścia nadzorczego i praktyki. 
Jednolity mechanizm nadzorczy, na który składają się EBC i krajowe organy nadzorcze, jest zintegrowaną strukturą ramową, której podstawowym celem jest nadzór ostrożnościowy nad instytucjami kredytowymi. Mechanizm nadzorczy oparty został na dwóch rozporządzeniach: pierwszym, regulującym organizację i procedurę jednolitego mechanizmu nadzorczego [Rozporządzenie Rady (UE) nr 1024/2013] i drugim, zmieniającym ramy prawne Europejskiego Urzędu Nadzoru w celu zapewnienia równowagi pomiędzy państwami należącymi do unii bankowej oraz tymi, które nie uczestniczącą w procedurze podejmowania decyzji [Rozporządzenie Parlamentu Europejskiego i Rady (UE) nr 1022/2013]. W ramach jednolitego mechanizmu nadzorczego EBC pełnić ma bezpośredni nadzór nad dużymi instytucjami kredytowymi o znaczeniu systemowym, natomiast w odniesieniu do mniej znaczących instytucji EBC odpowiada za autoryzację i weryfikację zasadniczych zmian w strukturze ich akcjonariatu, podczas gdy bieżący nadzór jest pozostawiony organom krajowym [Hadjiemmanuil 2015a]. Jeśli chodzi o planowanie i wykonywanie zadań powierzonych EBC, to zajmuje się nimi organ wewnętrzny, jakim jest Rada ds. Nadzoru, której skład tworzą: przewodniczący i wiceprzewodniczący oraz czterej przedstawiciele EBC (niewykonujący obowiązków bezpośrednio związanych z polityką pieniężną EBC), a także po jednym przedstawicielu organu krajowego z każdego uczestniczącego państwa. Decyzje głosowane są w trybie większości zwykłej, przy czym podejmowanie ostatecznych decyzji nie leży w gestii Rady ds. Nadzoru, lecz pozostaje w kompetencji Rady Prezesów EBC [Rozporządzenie Rady (UE) nr 1024/2013, art. 26 ust. 1, 5, 6 i 8].

Gdyby natomiast okazało się, że instytucja kredytowa nie tylko ma trudności finansowe, ale stoi u progu upadłości, wówczas zastosowany zostanie drugi mechanizm unii bankowej, tj. jednolity mechanizm restrukturyzacji i uporządkowanej likwidacji. Mechanizm ten zawiera procedury pozwalające na podejmowanie decyzji odnośnie do restrukturyzacji i uporządkowanej likwidacji instytucji kredytowych znajdujących się pod nadzorem EBC przy wsparciu środków pochodzących z jednolitego funduszu restrukturyzacji i uporządkowanej likwidacji, który jest finansowany przez sektor bankowy. Jednolity mechanizm restrukturyzacji i uporządkowanej likwidacji działa na podstawie rozporządzenia [Rozporządzenie Parlamentu Europejskiego i Rady (UE) nr 806/2014], które ustanawia Jednolitą Radę ds. Restrukturyzacji i Uporządkowanej Likwidacji, której skład tworzą: przewodniczący, czterej stali członkowie, przedstawiciele reprezentujący organy ds. restrukturyzacji i uporządkowanej likwidacji państw uczestniczących oraz przedstawiciele Komisji i EBC, mający status stałych obserwatorów z prawem uczestniczenia w sesjach wykonawczych i sesjach plenarnych (art. 43). Rada pozostaje centralnym organem ds. restrukturyzacji i uporządkowanej likwidacji odpowiedzialnym za sporządzanie planów oraz za przyjmowanie wszelkich decyzji w tym zakresie. Dodać należy, że państwa członkowskie (z wyjątkiem 
Szwecji i Wielkiej Brytanii) w maju 2014 r. podpisały Umowę o przekazywaniu i uwspólnianiu składek na rzecz jednolitego funduszu restrukturyzacji i uporządkowanej likwidacji [2014] ${ }^{6}$. Umowa, która została zawarta poza ramami traktatów, zobowiązuje strony do przekazywania do funduszu składek pobieranych od instytucji kredytowych posiadających zezwolenie na prowadzenie działalności na terytorium państwa będącego stroną umowy.

Warto podkreślić, że jednolitym mechanizmem restrukturyzacji i uporządkowanej likwidacji objęte zostały wszystkie instytucje kredytowe ustanowione w państwach strefy euro, jak również w tych państwach, które nawiązały współpracę z EBC w ramach tzw. bliskiej współpracy [Rozporządzenie Parlamentu Europejskiego i Rady (UE) nr 806/2014, art. 2 i 4]. Rada pozostaje natomiast odpowiedzialna za sporządzanie i przyjmowanie planów restrukturyzacji i uporządkowanej likwidacji w stosunku do tych instytucji kredytowych, które zostały objęte bezpośrednim nadzorem ostrożnościowym przez EBC, podczas gdy krajowe organy ds. restrukturyzacji i uporządkowanej likwidacji wspierają Radę w tym zadaniu, będąc jednocześnie odpowiedzialne za mniej znaczące instytucje kredytowe, sporządzając i przyjmując plany restrukturyzacji i uporządkowanej likwidacji w odniesieniu do tych podmiotów (art. 9). Ponadto zasadnicze decyzje dotyczące restrukturyzacji i uporządkowanej likwidacji w stosunku do instytucji kredytowych znajdujących się pod nadzorem EBC, jak również w odniesieniu do tych podmiotów, które znajdują się pod nadzorem krajowych organów ds. restrukturyzacji i uporządkowanej likwidacji, lecz które wymagają wsparcia z jednolitego funduszu restrukturyzacji i uporządkowanej likwidacji, podejmowane są przez Radę, natomiast realizacja programu restrukturyzacji i uporządkowanej likwidacji pozostawiona jest organom krajowym ds. restrukturyzacji i uporządkowanej likwidacji [Hadjiemmanuil 2015b].

Wspomniane mechanizmy działają na podstawie jednolitego zbioru przepisów odnoszących się do nadzoru ostrożnościowego, przy czym należy zauważyć, że zbiór ten nie powstał ze względu na potrzeby strefy euro ani też unii bankowej ${ }^{7}$ Jednolity zbiór przepisów określa wymogi kapitałowe [Rozporządzenie Parlamentu Europejskiego i Rady (UE) nr 575/2013, Dyrektywa Parlamentu Europej-

\footnotetext{
${ }^{6}$ Umowa międzyrządowa o przekazywaniu i uwspólnianiu składek na rzecz jednolitego funduszu restrukturyzacji i uporządkowanej likwidacji została ratyfikowana przez państwa członkowskie, co umożliwiło z dniem 1 stycznia 2016 r. pełne funkcjonowanie jednolitego mechanizmu restrukturyzacji i uporządkowanej likwidacji z wykorzystaniem instrumentu umorzenia oraz konwersji długu.

${ }^{7}$ Rada Europejska na spotkaniu na szczycie w czerwcu 2009 r. wezwała do ustanowienia europejskiego systemu organów nadzoru finansowego oraz jednolitej europejskiej księgi zasad, która miałaby zastosowanie do wszystkich instytucji finansowych na jednolitym rynku. Zob. Konkluzje prezydencji, Rada Europejska, Bruksela, 18-19 czerwca 2009 r., s. 8, http://register. consilium.europa.eu/doc/srv?l=PL\&f=ST\%2011225\%202009\%20INIT (data dostępu: 30.11.2016).
} 
skiego i Rady 2013/36/UE], systemy gwarancji depozytów [Dyrektywa Parlamentu Europejskiego i Rady 2014/49/UE] oraz zarządzanie instytucjami kredytowymi znajdującymi się u progu upadłości [Dyrektywa Parlamentu Europejskiego i Rady 2014/59/UE]. Jednolity zbiór przepisów tworzy w pełni zharmonizowane ramy odnoszące się do nadzoru ostrożnościowego nad instytucjami kredytowymi, jak również na potrzeby prowadzenia działań naprawczych oraz restrukturyzacji i uporządkowanej likwidacji instytucji kredytowych i firm inwestycyjnych. Ma on zastosowanie we wszystkich państwach Unii, jak również w państwach należących do Europejskiego Obszaru Gospodarczego (EOG). Jednolity zbiór przepisów uważany jest nierzadko za trzeci filar unii bankowej obok jednolitego mechanizmu nadzorczego oraz jednolitego mechanizmu restrukturyzacji i uporządkowanej likwidacji.

Niezależnie jednak od tego, że jednolity zbiór przepisów jest często uważany za trzeci filar unii bankowej (podobnie jak w przypadku bezpośredniego instrumentu dokapitalizowania - EMS ${ }^{8}$, trzecim, brakującym filarem unii bankowej jest jednolity mechanizm gwarantowania depozytów. Pomimo formalnego zakończenia prac nad tworzeniem unii bankowej brakuje nadal trzeciego filara w postaci jednolitego mechanizmu gwarantowania depozytów ${ }^{9}$ i w związku z tym odpowiedzialność za gwarantowanie depozytów w państwach strefy euro nadal pozostaje w gestii organów krajowych, chociaż nadzór i ewentualna decyzja o tym, że bank kwalifikuje się do upadłości, pozostaje w kompetencji EBC. Stąd wniosek, że właściwe funkcjonowanie unii bankowej wymaga utworzenia wszystkich trzech filarów na szczeblu ponadnarodowym. W sytuacji gdy nadzór sprawowany jest przez organ centralny, jakim jest EBC, odpowiedzialność za bezpieczeństwo depozytów zgromadzonych w bankach winna być również scentralizowana, a tym samym uniezależniona od sytuacji fiskalnej państwa [Ekonomiczne wyzwanie... 2014].

\section{Uwagi końcowe}

Rozpatrując kwestie związane z zarządzaniem rynkiem finansowym UE, należy wziąć pod uwagę to, że polityka monetarna stanowi scentralizowany reżim i powierzona jest EBC, natomiast polityka gospodarcza ma charakter zdecentrali-

${ }^{8}$ Zob. [Statement by the President... 2014]. Dotychczas EMS dysponował jedynie pośrednim instrumentem dokapitalizowania, który sprowadzał się do udzielania pożyczek rządom państw, które następnie dokapitalizowały instytucje finansowe [Treaty establishing the European... 2012].

${ }^{9} 24$ listopada 2015 r. Komisja przedstawiła wniosek ustawodawczy, którego celem jest uzupełnienie unii bankowej o dodatkowy element, mianowicie europejski system gwarantowania depozytów, który ma opierać się na krajowych systemach gwarantowania depozytów. Zob. [Wniosek... 2015]. 
zowany i podlega procedurze koordynacji. Unia monetarna nie podlega dyskusji, natomiast w przypadku unii gospodarczej (czy też unii fiskalnej i finansowej) mogliśmy dotychczas co najwyżej mówić o koordynacji działań państw członkowskich na szczeblu unijnym.

Konieczność zaradzenia skutkom kryzysu finansowego wiązała się m.in. z kontynuowaniem już wcześniej zainicjowanych reform, zwłaszcza w odniesieniu do rynku finansowego. Początkowo działania ograniczały się do miękkich mechanizmów koordynacji, takich jak: komisje, wytyczne, zalecenia i wzajemna weryfikacja, natomiast presja związana z kryzysem finansowym doprowadziła do ich stopniowego przekształcania w twarde. Reformy sprzyjały przejściu od reguł opartych na zasadach i minimalnej harmonizacji do bardziej nakazowych. Podobnie prawo miękkie w formie niewiążących wytycznych przekształcane było w charakterystyczne dla prawa twardego wiążące standardy techniczne jednolitego zbioru przepisów [Ekonomiczne wyzwania... 2014].

Obecnie obok działań podejmowanych w celu zwiększenia koordynacji gospodarczej w UE na pierwszy plan wysuwają się działania związane z unią bankową. Brak trzeciego filara unii bankowej, tj. jednolitego mechanizmu gwarantowania depozytów, stwarza poważne obawy, że europejska sieć bezpieczeństwa finansowego nie zapewni pełnej realizacji celu unii bankowej, jakim jest wyeliminowanie negatywnego sprzężenia pomiędzy kondycją banków a stanem finansów publicznych [Ekonomiczne wyzwania... 2014].

Należy też zauważyć, że fragmentaryzacja polityki w stosunku do instytucji kredytowych uważana jest za zasadniczą przeszkodę w działaniach na rzecz poprawy sytuacji państw peryferyjnych. Uwspólnienie odpowiedzialności za ratowanie instytucji kredytowych jest zatem pierwszym krokiem zmierzającym do zmiany tej sytuacji, przyczyniającym się zarazem do realizacji celów wspólnego rynku i unii monetarnej [Hadjiemmanuil 2015b]. Mechanizmy te nie działają jednak w sposób automatyczny, wymagają bowiem każdorazowo podjęcia stosownych decyzji, które niejednokrotnie determinowane są bieżącą sytuacją polityczną.

Reforma reżimu Unii (regulacja rynków finansowych) wzmocniła przede wszystkim władzę ekspertów. Szerokie delegowanie władzy od Rady i Parlamentu do komisji nadzorczych zwiększyło co prawda skuteczność polityki, lecz nie skuteczność polityki UE w ogóle. Poprawienie skuteczności polityki jest efektem zastosowania nowoczesnych narzędzi polityki, takich jak: programy działania, oddelegowanie ekspertów czy też transparentność konsultacji. Wcześniejsze trudne kompromisy były wkomponowane w wytyczne prawa miękkiego, które przyjmowano w trybie jednomyślności, właściwym dla nowego rządzenia. Kolejne reformy spowodowały jednakże, że wytyczne przekształcone zostały w wiążące standardy techniczne, co do których decyzje komisje mogły już przyjmować w trybie większości kwalifikowanej. 
Globalny kryzys finansowy obnażył słabości i niedostatki wynikające z braku jednolitego systemu finansowego, w tym zwłaszcza systemu bankowego. Powiązania pomiędzy krajowymi systemami bankowymi zaczęły ulegać fragmentaryzacji i zmierzać w kierunku renacjonalizacji rynków, zaś istniejące ramy regulacyjne okazały się niewystarczające do przeciwdziałania temu negatywnemu zjawisku, wydaje się więc, że w tym przypadku rozwiązanie może stanowić jednolity rynek finansowy, którego pierwszym etapem jest unia bankowa [Nosiadek 2014].

Powstaje pytanie, czy istotnie mamy do czynienia z nowym modelem rządzenia w UE. Jak wiadomo, Unia sięgała początkowo po instrumenty prawa miękkiego, a następnie dochodziło do tzw. utwardzania prawa miękkiego. Mimo to można jednak stwierdzić, że działania antykryzysowe znacząco wpłynęły na zmianę unijnego systemu rządzenia, co manifestuje się m.in. w sięganiu po instrumenty prawa międzynarodowego, prawa miękkiego oraz zwiększaniu kompetencji niektórych instytucji unijnych, czy też tworzeniu niezależnych agencji regulacyjnych.

Podsumowując, analiza przemian w unijnym systemie rządzenia następujących w reakcji na zjawiska kryzysowe potwierdza postawioną na wstępie hipotezę dokonało się istotne wzmocnienie gospodarczego filara UE, natomiast budowanie unii politycznej, które jest zadaniem znacznie trudniejszym, jest nadal sprawą otwartą, wymagać będzie bowiem renegocjacji traktatów.

\section{Literatura}

Alexander K. [2015], European Banking Union: A Legal and Institutional Analysis of the Single Supervisory Mechanism and the Single Resolution Mechanism, „European Law Review", nr 2.

Baglioni A. [2016], The European Banking Union. A Critical Assessment, Palgrave Macmillan, London.

Decyzja Komisji 2004/5/WE z dnia 5 listopada 2003 r. ustanawiająca Komitet Europejskich Organów Nadzoru Bankowego, Dz.Urz. UE L 3/28 7.1.2004.

Decyzja Komisji 2004/10/WE z dnia 5 listopada 2003 r. ustanawiająca Europejski Komitet Bankowy, Dz.Urz. UE L 3/36 7.1.2004.

Dehousse R. [2016], Has the European Union Moved towards Soft Governance?, „Comparative European Politics", vol. 14, nr 1, https://doi.org/10.1057/cep.2015.7.

Directive 2000/12/EC of the European Parliament and of the Council of 20 March 2000 relating to the taking up and pursuit of the business of credit institutions, OJ L 126, 26.5.2000.

Dyrektywa Parlamentu Europejskiego i Rady 2013/36/UE z dnia 26 czerwca 2013 r. w sprawie warunków dopuszczenia instytucji kredytowych do działalności oraz nadzoru ostrożnościowego nad instytucjami kredytowymi i firmami inwestycyjnymi, zmieniająca dyrektywę 2002/87/WE i uchylająca dyrektywy 2006/48/WE oraz 2006/49/WE, Dz.U. L 176/338 27.6.2013. 
Dyrektywa Parlamentu Europejskiego i Rady 2014/49/UE z dnia 16 kwietnia 2014 r. w sprawie systemów gwarancji depozytów, Dz.U. L 173/149 12.6.2014.

Dyrektywa Parlamentu Europejskiego i Rady 2014/59/UE z dnia 15 maja 2014 r. ustanawiająca ramy na potrzeby prowadzenia działań naprawczych oraz restrukturyzacji i uporządkowanej likwidacji w odniesieniu do instytucji kredytowych i firm inwestycyjnych oraz zmieniająca dyrektywę Rady 82/891/EWG i dyrektywy Parlamentu Europejskiego i Rady 2001/24/WE, 2002/47/WE, 2004/25/WE, 2005/56/WE, 2007/36/WE, 2011/35/UE, 2012/30/UE i 2013/36/EU oraz rozporządzenia Parlamentu Europejskiego i Rady (UE) nr 1093/2010 i (UE) nr 648/2012, Dz.U. L 173/190 12.6.2014.

Ekonomiczne wyzwania Polski ze strefa euro [2014], NBP, Warszawa.

Final Report of the Committee of Wise Men on the Regulation of European Securities Markets [2001], Brussels, 15 February, http://ec.europa.eu/internal_market/securities/ docs/lamfalussy/wisemen/final-report-wise-men_en.pdf (data dostępu: 30.11.2016).

Financial Services: Implementing the Framework for financial markets: Action Plan, Communication of the Commission, COM(1999) 232, 11.05.99.

First Council Directive (77/780/EEC) of 12 December 1977 on the coordination of laws, regulations and administrative provisions relating to the taking up and pursuit of the business of credit institutions, OJ EC L 322/30, 17.12.77.

Hadjiemmanuil Ch. [2015a], The Banking Union and Its Implications for Private Law: A Comment, EUI Working Paper, RSCAS, nr 74.

Hadjiemmanuil Ch. [2015b], Bank Resolution Financing in the Banking Union, LSE Law, Society and Economy Working Papers, nr 6.

Juncker J.C., Tusk D., Dijsselbloem J., Draghi M., Schulz M. [2015], Dokończenie budowy europejskiej Unii Gospodarczej $i$ Walutowej, Komisja Europejska, Bruksela, https:// ec.europa.eu/priorities/sites/beta-political/files/5-presidents-report_pl.pdf (data dostępu: 30.10.2016).

Kudrna Z. [2016], Governing the EU Financial Markets, „Comparative European Politics", vol. 14, nr 1, https://doi.org/10.1057/cep.2015.10.

Nosiadek G. [2014], Unia Bankowa krajów Unii Europejskiej, „Myśl Ekonomiczna i Polityczna", nr 3.

Rozporządzenie Parlamentu Europejskiego i Rady (UE) nr 1093/2010 z dnia 24 listopada 2010 r. w sprawie ustanowienia Europejskiego Urzędu Nadzoru (Europejskiego Urzędu Nadzoru Bankowego), zmiany decyzji nr 716/2009/WE oraz uchylenia decyzji Komisji 2009/78/WE, Dz.Urz. UE L 331/12 15.12.2010.

Rozporządzenie Parlamentu Europejskiego i Rady (UE) nr 575/2013 z dnia 26 czerwca 2013 r. w sprawie wymogów ostrożnościowych dla instytucji kredytowych i firm inwestycyjnych, zmieniające rozporządzenie (UE) nr 648/2012, Dz.U. L 176/1 27.6.2013.

Rozporządzenie Parlamentu Europejskiego i Rady (UE) nr 1022/2013 z dnia 22 października 2013 r. zmieniające rozporządzenie (UE) nr 1093/2010 w sprawie ustanowienia Europejskiego Urzędu Nadzoru (Europejskiego Urzędu Nadzoru Bankowego) w odniesieniu do powierzenia Europejskiemu Bankowi Centralnemu szczególnych zadań, Dz.U. UE L 287/5, 29.10.2013.

Rozporządzenie Parlamentu Europejskiego i Rady (UE) nr 806/2014 z dnia 15 lipca 2014 r. ustanawiające jednolite zasady i jednolitą procedurę restrukturyzacji i uporządkowanej likwidacji instytucji kredytowych i niektórych firm inwestycyjnych w ramach jednolitego mechanizmu restrukturyzacji i uporządkowanej likwidacji oraz jednoli- 
tego funduszu restrukturyzacji i uporządkowanej likwidacji oraz zmieniające rozporządzenie (UE) nr 1093/2010, Dz.U. L 225/1 30.7.2014.

Rozporządzenie Rady (UE) nr 1024/2013 z dnia 15 października 2013 r. powierzające Europejskiemu Bankowi Centralnemu szczególne zadania w odniesieniu do polityki związanej z nadzorem ostrożnościowym nad instytucjami kredytowymi, Dz.U. UE L 287/63, 29.10.2013.

Statement by the President of the Eurogroup: ESM direct recapitalisation instrument, 10 June 2014, http://www.consilium.europa.eu/uedocs/cms_data/docs/pressdata/en/ ecofin/143163.pdf (data dostępu: 30.10.2016).

Treaty establishing the European Stability Mechanism [2012], http://www.esm.europa.eu/ about/legal-documents/ESM\%20Treaty.htm (data dostępu: 30.10.2016).

Umowa o przekazywaniu i uwspólnianiu składek na rzecz jednolitego funduszu restrukturyzacji i uporządkowanej likwidacji [2014], Rada Unii Europejskiej, Bruksela, 14 maja, http://register.consilium.europa.eu/doc/srv?f=ST+8457+2014+INIT\&l=pl (data dostępu: 30.11.2016).

Wniosek. Rozporządzenie Parlamentu Europejskiego i Rady zmieniające rozporządzenie (UE) nr 806/2014 w celu ustanowienia europejskiego systemu gwarantowania depozytów, Strasburg, 24.11.2015 r., COM(2015) 586 final.

\section{The European Union's Post-crisis Governance (Abstract)}

The article provides an analysis of the European Union's post-crisis governance in order to answer the following questions: how is that governance shaped and what is the direction of the measures taken. In other words, are we dealing with the creation of an economic union, a financial union, a fiscal union, or perhaps establishing the foundations for a political union? Analytical, descriptive and systemic research methods were applied in this study, and allow the conclusion to be drawn that we are indeed witnessing a new model of governance taking form. However, while the Union's economic dimension has been strengthened, its political dimension remains substantially unchanged.

Keywords: European Union, crisis, banking union, financial markets. 